\title{
RESIDENT ALIENS AND TRANSLOCAL MERCHANT COLLEGIA IN THE ROMAN EMPIRE
}

\section{K. Verboven}

Boundaries are essential features of society. They determine the limits within which specific normative behavior is required. They define the 'ins' and the 'outs' and distinguish those to whom we are bound by socially prescribed ties of group related solidarity and respect from those who remain unbound by the impersonal rules of group related morality. ${ }^{1}$

The greatest achievement of the Roman empire was that it succeeded in creating an imagined community based on Roman citizenship, which transcended the local level. Inside this grand imagined community, however, thousands of smaller communities organized in cities, tribes and nations, continued to provide the setting for social life. Under the technological conditions characterizing the empire, social life largely remained local life. Local communities (patriae) remained strong moral communities, based on local citizenship, ethnicity or tribal membership.

Nevertheless, as argued by Horden and Purcell, ${ }^{2}$ mobility was the essence of the Mediterranean and of the Roman Empire. Ports and major cities were familiar with smaller or larger communities of migrants, resident aliens, and passing merchants. Ethnic groups and civic communities were bound together in a continuous exchange of outsiders frequenting and settling in each other's communities, spreading news and establishing links between distant places. ${ }^{3}$

Problems and challenges were inevitable. Foreign communities sought to maintain their ethnic or cultural identity, preserving close ties with

1 This paper is largely based on research done at the Academia Belgica in Rome in March 2009. I would like to thank the staff of the Academia Belgica for their hospitality and support. Special thanks are due also to the Ecole Française de Rome and to the libraries of the British School and the American Academy.

${ }^{2}$ P. Horden-N. Purcell, The corrupting sea. A study of mediterranean history (Oxford 2000).

${ }^{3}$ On the institutional and legal aspects see O. Licandro, 'Domicilium e incolae tra repubblica e principato', in R. Compatangelo-Soussignan-Chr. Schwentzel (eds.), Étrangers dans la cité romaine (Actes du colloque de Valenciennes (14-15 octobre 2005) "Habiter une autre patrie": des incolae de la République aux peuples fédérés du Bas-Empire) (Rennes 2007), 43-76. 
their homeland, but also had to integrate in local communities. Translocal merchants needed reliable local contacts and stopping places. Host communities had to find ways to satisfy both groups, without alienating the autochthonous population. This paper studies the role of voluntary associations (collegia) of resident aliens (katoikountes, consistentes) and translocal merchants in this process. ${ }^{4}$

In $174 \mathrm{AD}$ the Tyrians of Puteoli sent a delegation to their mother city with a letter containing a request for financial aid. ${ }^{5}$ The Tyrian community in Puteoli (hoi en Potiolois katoikountes) had once been large and prosperous. Their statio was still the largest and most splendid in the city. But as a result (no doubt) of the growing importance of Ostia and Portus, their numbers and prosperity had declined and financial burdens had become increasingly difficult to shoulder. They had to finance and perform the sacrifices and rites to the paternal gods of Tyre in various temples, and were charged with the munus of paying the bull sacrifice at the games in Puteoli. In addition, they paid for the upkeep of the statio and its decoration on the imperial sacred days. Contrary to the Tyrian statio at Rome, the statio in Puteoli did not receive contributions from shippers and merchants. Therefore they requested that the city of Tyre would henceforth pay the rent of 250 denarii for the statio to ensure its continued existence. ${ }^{6}$

The request was opposed by Philokles son of Diodoros, who revealed that the Tyrian stationarii in Rome had until then paid the misthos on behalf of the Puteoleans (presumably because they originated as an off-spring of the Puteolean statio when the port of Ostia opened). The Tyrians based in Rome refused to continue this arrangement and the Puteolean group faced the additional expense, for which they requested help from Tyre. Philokles proposed instead that both clubs should merge into a new association. The Tyrians from Puteoli replied by producing a document to prove that the city of Tyre had provided for two stationes. Unfortunately the text breaks off at this point. Presumably, since the

\footnotetext{
${ }^{4}$ J.R. Patterson, 'The collegia and the transformation of Italian towns', in L'Italie d'Auguste à Dioclétien (Rome 1994), 237; N. Tran, Les membres des associations romaines: le rang social des collegiati en Italie et en Gaules, sous le Haut-Empire (Rome 2006), 273294; H. Mouritsen, Plebs and Politics in the Late Roman Republic (Cambridge 2000), 84. For reasons of space strictly local collegia accepting foreigners in their ranks will be excluded.

${ }^{5} C I G$ 03, $5853=I G 14,0830$. For the best recent edition and analysis (with further bibliography) see J.D. Sosin, 'Tyrian "stationarii" at Puteoli', Tyche 14 (1999), 275-284.

${ }^{6}$ Mommsen and others read C(entum (milia)) N(ummum), 100,00o denarii. But see against this persuasively Sosin (loc. cit.): $\mathrm{CN}=\sigma v=250$ (drachmai).
} 
inscription was erected in Puteoli, their view had prevailed and the subsidy was accorded.

The inscription relating the case of the Tyrian stationarii is the richest document we have on an association of foreign residents. It documents its importance as a cult association, its relation with its home and its host city, its relation to a sister association and its relations with shippers and merchants. It is not, however, the only foreigners' club on record in Puteoli. Clubs are attested in the first and second century of Berytenses, Heliopolitanenses (Baalbek), Germellenses, and Nabataenses, besides many individual foreigners (merchants for the most part) and inscriptions attesting oriental cults. ${ }^{7}$ A graffito attests the existence of compitani Daphnenses (probably) from Antiochia. ${ }^{8}$ A vicus Tyanianus in Puteoli mentioned in a graffito in Herculaneum suggests a Cappadocian community. ${ }^{9}$ Foreign communities as these, prominent enough to lend their names to quarters of the city, undoubtedly had their own cult associations and scholae. Apart perhaps from its size and splendor there is no reason to believe that the Tyrian statio was exceptional.

Puteoli was an exceptional place. Like Ostia, the city was a commercial stronghold, where the number of outsiders rivaled the numbers of citizens. Both towns shared many features, but differed substantially from 'ordinary' cities. ${ }^{10}$ Nevertheless, collegia grouping foreigners are widely, although not abundantly, attested throughout the empire. In Rome (for obvious reasons) stationes municipiorum and stationes civitatum exterarum were common, some of them situated in the heart of the city on and near the forum. We find groups and stationes attested of Anazarbus, Ephesus, Heraclea, Mopsuestia, Tarsus, Tyre, Nysa, Sardis, Tralles, Tiberias and Claudiopolis. ${ }^{11}$

${ }^{7}$ G. Camodeca, 'Communità di "peregrini” a Puteoli nei primi due secoli dell'impero', in M. Bertinelli-A. Donati (eds.), Le vie della storia. Migrazioni di popoli, viaggi di individui, circolazione di idee nel Mediterraneo antico (atti del II incontro internazionale di Storia Antica, Genova 2004) (Roma 2006) (= Serta antiqua et mediaevalia 9), 269-287.

${ }^{8} A E$ 1932, $0071=H D$ 25203; G. Soricelli, 'Comunità orientali a Puteoli', in Compatangelo-Soussignan-Schwentzel (2007), op. cit. (n. 3), 133; D. Steuernagel, Kult und Alltag in römischen Hafenstädten: soziale Prozesse in archäologischer Perspektive (Stuttgart 2004), 46, nr. 170.

${ }^{9}$ CIL 4, 10676; Ostraka 9 (2000), 281-285; Soricelli 2007, op. cit. (n. 8), 133. Compare also infra n. 42 on the pagus Tyrianus.

${ }^{10}$ Cf. J. D'Arms, 'Puteoli in the second century of the Roman empire: a social and economic study', Journal of Roman Studies 64 (1974), 112.

${ }^{11}$ D. Noy, Foreigners at Rome. Citizens and strangers (London 2000), 160-161. IGUR 70-78, no. 78-93; L. Moretti, 'Sulle "stationes municipiorum" del Foro Romano', 
In most places the number or foreign residents was too small to support such specific clubs. In Malaca the Syrian and Asian community formed a single association. ${ }^{12}$ In Dacia we find collegia of Galatians, possibly grouping all Asian residents. ${ }^{13}$ In the German provinces we find collegia of peregrini. ${ }^{14}$ Even in Rome, we find a common statio for the entire province of Noricum. ${ }^{15}$

The model for such foreign resident associations goes back to preRoman times. Their essentially Mediterranean and Hellenistic character is illustrated by the Rhodian associations of the third and early second century $\mathrm{BCE},{ }^{16}$ the clubs of Romans and other nationalities at secondand first-century BCE Delos, ${ }^{17}$ and the conventus civium Romanorum throughout the empire in primarily the Republican period. ${ }^{18}$

Foreigners' associations not only tended to resident aliens, but also provided services to visiting merchants and shippers. The distinction between both groups was blurry, since resident aliens themselves were mostly merchants and merchants' agents. Nevertheless, the letter of the Tyrian stationarii expressly distinguishes the resident stationarii (katoi-

Athenaeum n.s. 36 (1958), 106-116; C. Ricci, Orbis in urbe. Fenomeni migratory nella Roma imperial (Roma 2005), 57-60.

12 CIL 2, p. $251=$ CIGR 26 cf. J.M. Santero Santurino, Asociaciones populares en Hispania Romana (Sevilla 1978), p. 165, no. 115.

${ }^{13} C_{1 L} 3,860=A E 2004,1182=H D 47075$.

${ }_{14} C_{1 L}{ }_{13}, 8808$ (2, p. $31^{\star}$ ) (Forum Hadriani); CIL 13, $11750=$ HD 36883 (Waldheim); CIL 13, 06453 (Marbach).

${ }^{15}$ CIL 6, 250 $=30723=H D 1133$ (note also the forged copy of the same inscription on an urn $A E$ 1982, 162).

${ }^{16}$ V. Gabrielsen, 'The Rhodian Associations and Economic Activity', in Z. Archibald et al. (eds.), Hellenistic economies (London-New York 2001), 163-184.

17 J.-M. Flambard, 'Observations sur la nature des magistri italiens de Délos', in F. Coarelli-D. Musti-H. Solin (eds.), Delo e l'Italia (Roma 1982), 67-77; C. Hasenohr, 'Les collèges de magistri et la communauté italienne de Délos', in C. Müller-C. Hasenohr (eds.), Les Italiens dans le monde grec: IIe siècle av. J.-C.-Ier siècle ap. J.-C.: circulation, activités, intégration (Actes table ronde, École normale supérieure, Paris, 1998) (Athènes 2002), 67-76; C. Hasenohr, 'Les "Compitalia" à Délos', Bulletin de Correspondance Hellénique 127 (2003), 167-249; Note for instance the Heracleistes de Tyre and the Posidoniastes of Beritus: C. Hasenohr, 'Italiens et Phéniciens à Délos: organisation et relations de deux groupes détrangers résidents (IIe-Ier siècles av. J.-C.)', in R. CompatangeloSoussignan-Chr.-G. Schwentzel, Etrangers dans la cité romaine (Actes du colloque de Valenciennes (14-15 octobre 2005) "Habiter une autre patrie": des incolae de la République aux peuples fédérés du Bas-Empire) (Rennes 2007), 91-109.

${ }^{18} \mathrm{~W}$. Van Andringa, 'Cités et communautés d'expatriés installées dans l'Empire romain: le cas des cives Romani consistentes', in N. Belayche-S.C. Mimouni (eds.), Les communautés religieuses dans le monde gréco-romain. Essais de définition (Turnhout 2003), 49-60. 
kountes) in Rome and Puteoli from merchants and shippers. The Roman statio received income from the latter, while the Puteolean did not. Possibly, the Roman stationarii charged 'costs' for the facilities offered by the statio. These may have included performing rites and sacrifices, but laying contacts, obtaining introductions, finding lodgings and storing facilities etc. could likewise have persuaded merchants and shippers to contribute to the statio's expenses.

Collegia of residents aliens maintained close relations with their home cities. The case of the Tyrian stationarii suggests that the home city at least had moral authority over their emigrant communities. The request that Tyre should pay the rent for their statio is not without parallel. Salvidienus Orfitus was charged for plotting against Nero because he had hired out three tabernae of his house near the forum to cities for use as stationes. ${ }^{19}$ In the case of the Tyrians the clubs at Rome and Puteoli operated independently, but this need not always have been the case. Particularly in Rome public stationes, with stationarii acting under instruction and on behalf of their patria, may have been common. The city of Gaza erected a statue with honorary inscription in Portus to Gordian on order of its ancestral god, under supervision of Ti. Claudius Papirius, epimelètès of the sanctuary of Marnas at Ostia-Portus. The fact that a citizen from Ostia served as the sanctuary's supervisor argues against the presence of a strong Gazan community. ${ }^{20}$

Diodoros' proposal that the Roman and the Puteolean association of Tyrians should merge into a single translocal association may have been inspired by the prevalent model of translocal merchant associations that seems to have gained importance in the second century CE. In Ostia numerous collegia of negotiantes and navicularii are attested. They are differentiated according to their origin and (sometimes) specialty: the olearii ex Baetica, the navicularii Misuenses, the navicularii Karthaginienses, the Sabratenses, .... At least 12 (possibly 13) of the stationes at the 'Piazzale delle Corporazioni' belong to foreign merchants and shippers. ${ }^{21}$ Prominent members undoubtedly resided at least partly in Ostia or Rome, but there is no reason to assume that only resident merchants or shippers became members of these associations, or that the associations relied on local communities of long term residents.

19 Suetonius, Nero 37.2.

20 I.Porto $5=I G$ 14, 926; See L. Ross Taylor, Cultus of Ostia (Bryn Mawr 1912), 79-89.

$21 \mathrm{CIL} \mathrm{14}, 4549$. On the role of the Ostian collegia in the integration of outsiders see Tran 2006, op. cit. (n. 4), 285-289. 
The corpus oleariorum had a statio in Rome or Ostia, but also one in Hispalis, where the daughter of a member, Valerius Valens, donated a statue of Venus Genetrix ad cultum operis to the corpus. ${ }^{22} \mathrm{~L}$. Marius Phoebus, mercator olearius ex Baetica acquired a position as viator tribunicius in Rome, where he died. But he and his son figure among the dedicants of the funerary inscription in honor of a certain Auge who died and was buried in Corduba. ${ }^{23}$ The presidents of the important olearii ex Baetica sometimes resided in Rome, but kept their estates and town houses in Baetica, where their families and descendents continued to live. Iulius Hermesianus, for instance, erected an epitaph for a freedwoman of his in Rome, but received statues in his honor from his son and the corpus oleariorum in Hispalis. ${ }^{24}$

The corpora of foreign negotiatores and navicularii in Rome and Ostia were well integrated in local life. The 'Piazzale delle Corporazioni' in Ostia is an important landmark in the city's public topography and emphatically links the corporations of foreign shippers and merchants to the city's theatre and its public festivals. At least from the time of Trajan onwards collegia of navicularii and negotiantes mediated in the extension of privileges to merchants and shippers working for the imperial annona, which greatly increased their prestige and influence. ${ }^{25}$

${ }^{22}$ AE 2002, 716; A.M. Canto, 'Addendum ad no. 577b', Hispania Epigraphica 10 (2000) [2004], 209-211.

${ }^{23}$ CIL 6, 1935; AE 2000, 734 = CIL 2(2), 7,544 (Cordoba); CIL 15, 3943-3959 (tituli picti from the Monte Testaccio); J. Remesal Rodríguez, 'L. Marius Phoebus mercator olei hipani ex provincia Baetica. Consideraciones en torno a los términos mercator, negotiator y diffusor olearius ex Baetica, in P. Gianfranco (ed.), Epigraphai. Miscellanea Epigrafica in onore di Lidio Gasperini (Roma 2000), 781-797.

${ }^{24}$ HEp 10, 576; CIL 6, 20742. G. Chic Garcia et al., 'Una nueva inscripción annonaria de Sevilla: M. Iulius Hermesianus, diffusor olei ad annonam urbi', Habis 32 (2001), 353374; P. Le Roux, 'L'huile de Bétique et le Prince. Sur un itinéraire annonaire', Revue des Etudes Anciennes 88 (1986), 247-271; U. Ehmig, 'Pinselaufschrift und stempel auf einer südspanischen Ölamphore aus Mogontiacum-Mainz-Who is who in familia M. Iulii Frontiniani?', Pyrenae 29 (1998), 237-248; A. Tchernia, 'D. Caecilius Hospitalis et M. Iulius Hermesianus (CIL 6, 1625b; 20742)', in J.M.B. Martínez (ed.), Producción y comercio del aceite en la Antiguëdad. Primer congreso Internacional (Madrid 1980), 155160; Cf. Chr. Rico, 'Mercatores, negotiatores et diffusores olearii et le commerce de l'huile de Bétique à destination de Rome aux Ier et IIe siècles de notre ère', Revue des Etudes Anciennes 105 (203), 413-433.

${ }^{25}$ B. Sirks, Food for Rome: the legal structure of the transportation and processing of supplies for the imperial distributions in Rome and Constantinople (Amsterdam 1991); L. De Salvo, Economia privata e pubblici servizi nell'impero romano: $i$ corpora naviculariorum (Messina 1992); E. Lo Cascio, 'Ancora sugli “Ostia’s services to Rome”: collegi 
The epitome and perhaps the original model for supralocal associations was provided by the Greek guilds of actors (Dionysitechnitai) and of athletes. They originated in the Hellenistic period and continued to thrive in the Principate, when they were styled 'world-wide associations'. Their importance to one of the core aspects of Greek 'High' culture made them influential with local and imperial elites, guaranteeing them even imperial protection. ${ }^{26}$

In Rome the Ephesian pancratist M. Ulpius Domesticus donated a building (?) dedicated to the emperor, to the city (?) of Ephesus and to the nauklèroi and emporoi of Ephesus. Whether the Ephesian merchants and shippers were organized in a translocal association that could have used the building as a statio is unknown. However, Ulpius Domesticus was also High Priest and president of the Roman Athletic Guild and patron of the international 'Sacred Guild of Athletes Devoted to Herakles'. He succeeded in obtaining from Antoninus Pius the donation of a spot of land near the baths of Trajan, where the splendid Curia Athletarum was built. ${ }^{27}$

Translocal merchant and shipper associations are commonly found also elsewhere.$^{28}$ In Lugdunum we find a large community of residents in canabis consistentes, that was closely linked to the colonia. Many consistentes were no doubt long term residents, but not all. The important corporations of the nautae Ararici, the nautae Rhodanici and the vinarii Lugduni consistentes, were firmly based in Lugdunum, where they erected

e corporazioni annonarie a Ostia', Mélanges de l'Ecole Française de Rome et d'Athènes 114 (2002), 87-109; W. Broekaert, 'Creatio ex nihilo? The Origin of the corpora nauiculariorum reconsidered', Latomus 67 (2008), 692-706.

${ }^{26}$ Z. Newby, Greek Athletics in the Roman World (Oxford 2006), 239-252; C.A. Forbes, 'Ancient athletic guilds', Classical Philology 50 (1955), 238-252; Caldelli 1992, op. cit. (n. 27); H.W. Pleket, 'Some aspects of the history of the Athletic Guilds', Zeitschrift för Papyrologie und Epigraphik 10 (1973), 197-227; V. Hirschmann, 'Macht durch Integration? Aspekte einer gesellschaftlichen Wechselwirking zwischen Verein und Stadt am Beispiel der Mysten und Techniten des Dionysos von Smyrna, in A. GutsfeldD.-A. Koch (eds.), Vereine, Synagogen und Gemeinden im kaiserzeitlichen Kleinasien (Tübingen 2006), 41-59.

${ }^{27}$ IGUR 26; Noy 2000, op. cit. (n. 11), 160-161; Forbes 1955, op. cit. (n. 26), 243-244; Newby 2006, op. cit. (n. 26), 34-36; M.I. Caldelli, 'Curia athletarum, iera xystike synodos e organizzazione delle termea Roma', Zeitschrift för Papyrologie und Epigraphik 93 (1992), 75-87.

${ }^{28}$ See Verboven 2007, op. cit. (n. 41), 873-875; K. Verboven, 'Magistrates, patrons and benefactors of collegia: status building and Romanisation in the Spanish, Gallic and German provinces', in B. Antela-Bernárdez-T. Ñaco del Hoyo (eds.), Transforming Historical Landscapes In The Ancient Empires (Oxford 2009), 163-164. 
honorary monuments, elected patrons and took part in the local and the provincial festivities. Their members, however, came from all over Gaul. ${ }^{29}$ The wine merchant and barge shipper Apronius Raptor, for instance, was honored in Lugdunum by the corpora of the nautae Ararici and the negotiatores vinarii Lugduni consistentes, but was a citizen and council member of Trier. ${ }^{30}$

Members from the Corpus splendissimum mercatorum Cisalpinorum et Transalpinorum are attested in Lugdunum, Aventicum, Mediolanum, Novara and indirectly in Trier. The association enjoyed high protection from senators and may have dominated the land routes over the Alps. ${ }^{31} \mathrm{~A}$ high ranking nobleman from Aventicum, Q. Otacilius Pollinus, who represented the Helvetii at the council of the Gauls and received three times tax-immunity from Hadrian, was honoured as patron of the Venalicii Cisalpinorum et Transalpinorum. In addition Pollinus was patron of the Helvetii and of the nautae Ararici et Rhodanici. ${ }^{32}$

An important function of collegia of alien residents and translocal businessmen was to forge and strengthen social relations between persons sharing the same background, customs and (mostly) profession. Collegia were above all 'brotherhoods'; closed groups with a select number of members tied together in bonds of trust and solidarity. ${ }^{33}$ This community aspect rested on three pillars: cult, commemoration and conviviality.

It was unthinkable in the ancient world that a community could exist without tutelary deities. Collegia were always also cult associations. ${ }^{34}$

29 Tran 2006, op. cit. (n. 4), 275-285.

${ }^{30} A E$ 1904, $176=$ CIL 13, 11179; CIL 13, 1911; L. Wierschowski, Fremde in Gallien'Gallier' in der Fremde. Die epigraphisch bezeugte Mobilität in, von und nach Gallien vom 1. Bis 3. Jh. n. Chr. (Stuttgart 2001), 318-319, no. 443.

${ }^{31}$ G. Walser, 'Corpus mercatorum Cisalpinorum et transalpinorum', Museum Helveticum 48 (1991), 169-175; A. Alföldi, 'La corporation des Transalpini et Cisalpini à Avenches', Suisse Primitive 16 (1952), 3-9; Verboven 2007, op. cit. (n. 41), 876-877; B. Tasser, 'Die Vereine der Cisalpini und Transalpini-eine Alpenumspannende Handelsgesellschaft?', in R. Lafer-K. Strobel (eds.), Die Geschichte der Antike aktuell: Methoden, Ergebnisse und Rezeption: Aktes des 9. gesamtösterreichischen Althistorik (KlagenfurtWien 2005), 187-198.

${ }^{32}$ CIL 13, 11480-11492 = AE 1995, 1141. On Otailius Pollinus: J. Reynolds, 'Q. Otacilius Pollinus of Aventicum', Pro Aventico 20 (1969), 53-57; R. Frei Stolba, 'Q. Otacilius Pollinus: inquisitor III Galliarum', in P. Kneissl-V. Losemann (eds.), Alte Geschichte und Wirtschaftsgeschichte (Darmstadt 1988), 186-201; H.E. Herzig, 'Die Familie der Otacilier in Aventicum', Jahrbuch des Bernischen Historischen Museums 53-54 (1973-1974), 35-41.

${ }^{33}$ Cf. the contubernium peregrinorum mentioned in CIL 13, $11750=H D 36883$.

${ }^{34}$ Cf. J.-P. Waltzing, Étude historique sur les corporations professionnelles chez les Romains: depuis les origines jusquà la chute de l'Empire d'Occident (Bruxelles-Louvain), 
The terms schola, statio and templum overlap and were mostly chosen merely to stress either profane or cultic aspects of an association. ${ }^{35}$ The question is never 'are we dealing with a religious association?', but rather what other purposes did the association serve and how did its religious dimensions contribute to this? In the case of clubs of foreign residents and translocal merchants, affirming and experiencing the community's cultural identity through the performance of common cult practices was of major importance.

The letter from the Tyrian stationarii at Puteoli is almost entirely focused on the cult practices it ensured for the gods of Tyre and the emperor. The citizens from Berytus residing in Puteoli describe themselves as cultores Iovis Heliopolitani Berytenses qui Puteolis consistunt. ${ }^{36}$ Another inscription (possibly referring to the same community) mentions the qui in cultu corporis Heliopolitanorum sunt. ${ }^{37}$

But 'national' gods are not the only deities being honored by foreigners' collegia. Residents from Bracaraugusta in Pax Iulia in Lusitania dedicated their schola (?) in the 2nd c. CE to Sol or to Mithra. ${ }^{38}$ In Marbach (Germania Superior) a member of the collegium peregrinorum offered a statue of Victoria with base to his collegium in fulfillment of a vow ${ }^{39}$ Two members of a collegium peregrinorum in Forum Hadriani dedicated a statue to the Genius of their collegium. ${ }^{40}$

Funeral and commemoration rites for deceased members, patrons and benefactors were a prime responsibility of all ancient collegia. ${ }^{41}$

I, 195-255; F. Ausbüttel, Untersuchungen zu den Vereinen im Westen des römischen Reiches (Kallmünz 1982), 29; J. Scheid, 'Communautés et communautés: réflexions sur quelques ambiguités d'après l'exemple des thiases dans l'Egypte romaine', in N. BelaycheS.C. Mimouni (eds.), Les communautés religieuses dans le monde gréco-romain. Essais de définition (Turnhout 2003).

${ }^{35}$ D. Steuernagel, "“Corporate identity": über Vereins-, Stadt- und Staatskulte im kaiserzeitlichen Puteoli', Mitteilungen des Deutschen Archaeologische Instituts Römische Abteilung 106 (1999), 161.

${ }^{36}$ Camodeca 2006, op. cit. (n. 7), 271-272.

37 CIL 10, 1679; V. Tran Tam Tinh, Le culte des divinités orientales en Campanie (Leiden 1972), 149; Steuernagel 1999, op. cit. (n. 35), 161; Camodeca 2006, op. cit. (n. 7).

${ }^{38} A E$ 1956, $254=A E$ 1984, 465; J.C. Edmonson, 'Mithras at Pax Iulia-a re-examination', Conimbriga 23 (1984), 72-85.

${ }^{39} \mathrm{CIL} 13_{13}, 6453$.

${ }^{40}$ CIL 13,8808 .

41 Th. Mommsen, De sodaliciis et collegiis Romanorum (Kiel 1843); K. Hopkins, Death and renewal (Cambridge 1983), 211-217; See J.S. Perry, A Death in the familia: the funerary colleges of the Roman Empire (Chapell Hill Diss. 1999); J. Patterson, 'Patronage, collegia and burial in imperial Rome', in S. Bassett (ed.), Death in towns: urban responses to the dying and the dead, 100-160o (Leicester 1992), 15-27; K. Verboven, 'The associative 
Collegia guaranteed a respectable funeral, provided funds for the upkeep of collective sepulchral monuments and burial plots, and ensured that their deceased members would be remembered and their last resting places kept in honor. Membership was not free. Accordingly, the main contribution of collegia was not financial but social. Their implication in the funerary and commemoration rituals for members, patrons and benefactors expressed the integration of the deceased and his family in the brotherhood of the collegium and remembered the honorable position once attained by deceased presidents, patrons and benefactors.

In Puteoli the corpus Heliopolitanorum owned 7 iugera of land, with a cistern and workshops. This large complex was no doubt intended inter alia for commemorative rituals practiced by the corpus. The letter from the Tyrian stationarii makes no mention of it, but the existence of a pagus Tyrianus with a taberna and kitchen indicates that Tyrians owned substantial property outside the town of Puteoli. Presumably part of this served for burials and funerary monuments. ${ }^{42}$

The kitchen points to the third core activity of ancient collegia: commensality. Collegiate life revolved around social gatherings for communal eating and drinking. In addition to regular more or less informal meetings, ${ }^{43}$ banquets were held to mark birthdays, marriages, religious events, etc. Donahue described such meetings as 'segregative commensality', intended to reinforce intra-group relations. Ascough, however, noted that the banquets fit better in the category of 'exceptional commensality. The calendar for banquets was mostly based on life cycle events of outsiders (emperors, benefactors, patrons ...) and public festivalsin the case of foreigners' collegia both of the host city and the members' homeland. ${ }^{44}$ Thus, they served to integrate foreigners' collegia symbolically in their host cities and to express the members' lasting relation with their patria.

One of the most obvious effects (and functions) of collegia and closely connected to their performance as communities was the creation of

order. Status and ethos among Roman businessmen in late republic and early empire', Athenaeum 95 (2007), 872-873.

${ }^{42}$ On the Heliopolitani cf. supra n. 37; on the pagus Tyrianus: Camodeca 2006, op. cit. (n. 7), 282-283: L. Domitius Pudens patro/nus pagi Tyriani tabernam et culinam cocinatoriam ob honore patronici (sic) / pecunia sua a solo fecit paganis pagi / Tyriani.

${ }^{43}$ Dig. 47.22.1.

44 J.F. Donahue, 'Toward a typology of Roman public feasting', American Journal of Philology 124 (2003), 423-441; R. Ascough, 'Forms of commensality in Greco-Roman associations', Classical World 102 (2008), 33-45. 
status positions. Collegia needed representatives, priests, protectors and benefactors. ${ }^{45}$ The ethnic and trans-local collegia conferred status upon their magistrates and protectors as mediators between local communities on the one hand and foreign residents and frequent visitors on the other. This tied the elites of foreign residents and merchants firmly into the social and political fabric of local communities and gave foreigners' clubs a place in local society and politics.

The inscription of the Tyrian stationarii records two persons who spoke in the assembly of Tyr when the request was debated. The association of the Germellenses honored their priest and son of their curator Aurelius Theodorus by giving him a torque and a velum. ${ }^{46}$ We already mentioned the honorary statue that Iulius Hermesianus, president of the olearii ex Baetica, received in Hispalis (cf. supra n. 24). Sentius Regulianus started his career as a wine merchant in Lyon, but began dealing in Baetican olive oil and rose through the ranks of their corporation, which brought him to Rome as their president. Here he became diffusor olearius, received the rank of eques romanus and eventually died. Although a resident of Rome at the time of his death, his wife and children appear to have lived elsewhere (probably their home-city Lugdunum). ${ }^{47}$

Clubs of foreign residents and translocal businessmen engaged in a symbolic interaction with their host communities expressing the integration of the collegia and their members in local life. They did so primarily by following the model laid out by prominent local collegia. Collegia in general were closely connected with public festivals. Seating arrangements in theaters, amphitheaters, stadia etc., laid down by laws and council decrees, were an important way to signify publicly acknowledged social positions. ${ }^{48}$ Important collegia had reserved seats in theaters throughout the empire. In the theatre of Aphrodisias seats

45 See on this aspect Verboven 2007, op. cit. (n. 41); Verboven 2009, op. cit. (n. 28).

46 CIL 10, 1578; V. Tran Tam Tinh, Le culte des divinités orientales en Campanie (Leiden 1972), 148-149; Camodeca 2006, op. cit. (n. 37), 272.

47 CIL 6, 29722; B. Rémy, 'Une grande famille ségusiave: les Ulattii', Revue Archéologique de l'Est et du Centre-Est 25 (1973), 92; J.P. Vallat, 'La cité des Ségusiaves à l'époque romaine', in S. Walker (ed.), Récentes recherches en archéologie gallo-romaine et paléochrétienne sur Lyon et sa région (Oxford 1981), 262-263.

48 J. Kolendo, 'La répartition des places aux spectacles et la stratification sociale dans l'empire romain', Ktèma 6 (1981), 301-315; 310-311; J.C. Edmondsen, 'Dynamic arenas: gladiatorial presentations in the city of Rome and the construction of Roman society during the early empire', in W.J. Slater (ed.), Roman theater and society. E. Togo Salmon Papers I (Ann Arbor 1996), 100-101; E. Rawson, 'Discrimina ordinum: the lex Iulia theatralis', Papers of the British School in Rome 55 (1987), 83-114. 
were reserved for tanners, gold-workers, gardeners, corn merchants (?), neighborhood associations, and a number of other clubs. ${ }^{49}$ At the other end of the empire, examples are attested in Nemausus, Lugdunum and Arelate. ${ }^{50}$ Foreign groups as well were given reserved seats. A number of seats in the Collosseum was reserved for Gaditani. ${ }^{51}$ In Lugdunum, seats were reserved for Macedones. ${ }^{52}$ In Aphrodisias we find reserved seats in the stadion for citizens of Mastaura and Antioch. ${ }^{53}$ Although membership of a local foreigners' association was most likely not required, they were presumably involved in the individual distribution of the seats.

Likewise, associations of translocal businessmen sometimes received reserved seats. At Nemausus the corporations of the nautae Atr(icae?) et Ovidis and the nautae Rhodanici et Ararici respectively had 25 and 40 seats in the theatre. ${ }^{54}$ At Arles the diffusores olearii (presumably elite members of the corpus oleariorum who served as diffusores at Rome) may have had reserved seats. ${ }^{55}$

The integration of foreigners' and translocal merchant collegia in local communities was not only visually expressed through seating arrangements. Scholae, temples and monuments belonging or referring to collegia formed an integral part of the public urban topography in important cities. In Puteoli, at least seven rooms on the outside of the amphitheater were used by various collegia. In Ostia the 'Piazzale delle Corporazioni', adjoining the theater, was the result of deliberate urban planning. The stationes at the Piazzale were most likely rented out to the corpora occupying them. Steuernagel rightly stresses the representational function of

\footnotetext{
${ }^{49}$ C. Roueché, Performers and partisans at Aphrodisias in the Roman and Late Roman Periods (London 1993),124-128.

${ }^{50}$ Nemausus: CIL 12, 3316; 3317; Lugdunum: A. Audin-J. Guey, Bulletin de la société nationale des antiquaires de France (1976), 201-202, no. 1; Arelate: CIL 12, 714, 1.

${ }^{51}$ CIL 6, 32098,l-m (not for official delegations, who received seats marked hospitibus publicis (CIL 6, 3298e; Roueché 1993, op. cit. (n. 49), 121)). Of course, a statio of the Gaditani in Rome may have been financed and supervised by Gades. On peregini in theaters in general see Rawson 1987, op. cit. (n. 48), 92-94.

${ }^{52} A E$ 2000, $0940=H D$ 47671; C. Vismara-M.L. Caldelli, Epigrafia anfiteatrale dell'Occidente romano. 5: Alpes Maritimae, Gallia Narbonensis, Tres Galliae, Germaniae, Britannia (Roma 2000), 124-125. Lugdunum was exceptional, because the theatre served at the yearly 'council of the Gauls' to which all Gallic civitates sent official representatives J. Guey-A. Audin, 'Lamphithéatre des Trois-Gaules à Lyon', Gallia 22 (1964), 37-58.

${ }_{53}$ Roueché 1993, op. cit. (n. 49), 121, nos. 45,4,O; 45.34.S.

${ }^{54}$ CIL 12, 3316; 3317; CIL 12, 3318e possibly mentioning reserved seats for nav(icularii).

${ }^{55}$ CIL 12, 714, 1.
} 
these stationes. ${ }^{56}$ By laying out the Piazzale in this way the city council emphatically put the translocal merchant corporations on a par with local collegia. Outside theaters too, public space was given to foreigners' and translocal merchant collegia. Thus the city council of Puteoli granted a public location for a stele commemorating the journey of Baal Sarepta to the city. ${ }^{57}$

Immaterial arrangements symbolizing the integration of foreigners' and translocal merchant collegia are badly documented, but are likely to have been as prominent. The Tyrian stationarii at Puteoli at least were charged with the bull sacrifice at the occasion of the municipal games (cf. supra).

Another way for foreigners' and translocal merchant associations to express their integration in local life was through participation in the honorific practices for local notables, public benefactors and patrons. These not only enhanced the social status of those who were being honored, but also served to claim relevance for the social opinions of those who did the honoring, thus affirming their rightful place in the moral community. ${ }^{58}$ In Ostia, the former grain merchant M. Iunius Faustus, who became duumvir of the city and flamen in the emperor cult, was co-opted as patron by the corporations of curatores of the African and of the Sardinian ships. ${ }^{59}$ In Barcino, the college of the Assotani, contributed a statue with marble base in the series of $20+$ such statues set up in or near the forum of Barcino in honor of L. Licinius Secundus, a powerful freedman accensus of the consular Licinius Sura. Secundus was elected sevir augustalis of Barcino and Tarraco. The collegium of the Assotani figures besides the ordo of Barcino, the ordo of the Iamontani, the ordo of Auso and the collegium of seviri augustales of Barcino. ${ }^{60}$

\footnotetext{
56 Steuernagel 1999, op. cit. (n. 35), 155-156. On the visibility of collegia in urban topography see Tran 2006, op. cit. (n. 4), 241-261; B. Bollmann, Römische Vereinshäuser. Untersuchungen zu den Scholae der römischen Berufs-, Kult- und Augustalen-Kollegien in Italien (Mainz 1998).

${ }^{57}$ IGRR 1,420; for edition and commentary V. Tran Tam Tin 1972, op. cit. (n. 37), 137; 156-158 (no. S 18, fig. 77), 18; P. Visona, 'Puteolana Analecta', Puteoli 9-1o (1985-1986), $50-57$.

58 See Verboven 2007, op. cit. (n. 41), 879; O. van Nijf, The Civic World of Professional Associations in the Roman East (Amsterdam 1997), 31-72.

${ }^{59}$ CIL 14, 4142; G. Rickman, The Corn Supply of the City of Rome (Oxford 1980), 91; R. Meiggs 1960, op. cit. (n. 25), 186; 209; 277.

${ }^{60}$ CIL 2, $4540(955,982)$. See F. Piernavieja, 'El 'collegium assotan(orum)' y otros similares', Archivo Espagnol de Arqueologia 50-51 (1977-1978), 437-443; Santurino 1978, op. cit. (n. 12), 124-125; 162, no. 96.
} 
Last but not least, foreigners' associations were dedicated to the imperial cult and joined local collegia and cities in celebrating the emperor. We may guess they did so enthusiastically, because ultimately their position depended on the strength of the empire. Thus, the Tyrian stationarii in Puteoli spent what they felt was a considerable sum on decorating their statio on imperial holy days. In Germisara in Dacia, the club of 'Galatians' dedicated an altar to Hercules Invictus for the well-being of the emperor. ${ }^{61} \mathrm{~A}$ similar inscription in honor of Jupiter Tavianus was erected by the Galatae consistentes for the well-being of Antoninus Pius and Marcus Aurelius Caesar in Napoca. ${ }^{62}$

Collegia in general provided a framework for urban life. They tied subelite citizens to the formal structures of the city dominated by local aristocracies whose wealth was largely based on landed estates and urban property, and they introduced dynamic status distinctions among subelite groups. ${ }^{63}$ Collegia of migrants, resident aliens and translocal businessmen did the same for foreigners residing in or frequenting local communities. They provided passage ways crossing through borders defined by the civic and imperial order, and-being micro-communities themselves-defined their own social boundaries crossing through civic frontiers. By doing so they facilitated and intensified the mobility of people, goods and ideas and thereby ultimately contributed to the cohesion of the empire.

Ghent, December 2009

${ }^{61}$ CIL 3, $1394=H D 45659$.

${ }^{62} C I L$ 3, 860; $A E$ 2004, 1182; AE 2004.

${ }^{63}$ Verboven 2007, op. cit. (n. 41). 